\title{
Association of polymorphisms of paraoxonase 1 and 2 genes, alone or in combination, with bone mineral density in community-dwelling Japanese
}

Received: 24 April 2003/ Accepted: 22 July 2003/Published online: 30 August 2003

(C) The Japan Society of Human Genetics and Springer-Verlag 2003

\begin{abstract}
Oxidative stress may affect cellular functions in various pathological conditions, including osteoporosis. Paraoxonase 1 confers antioxidant properties on highdensity lipoprotein, with which it is associated, by reducing the accumulation of lipid peroxidation products. We have now examined whether the $584 \mathrm{~A} \rightarrow \mathrm{G}$ (Gln192Arg) and 172T $\rightarrow$ A (Leu55Met) polymorphisms of the paraoxonase 1 gene and the $959 \mathrm{G} \rightarrow \mathrm{C}$ (Cys311Ser) polymorphism of the paraoxonase 2 gene are associated with bone mineral density (BMD) in community-dwelling Japanese (1,087-1,094 women and 1,112-1,125 men). The subjects were aged $40-79$ years and were randomly recruited to a population-based prospective cohort study of aging and age-related diseases. BMD for the lumbar spine and right femoral neck was measured by dual-energy X-ray absorptiometry. Genotypes were determined with a fluorescence- or colorimetry-based allele-specific DNA primer-probe assay system. The $584 \mathrm{~A} \rightarrow \mathrm{G}$ and $172 \mathrm{~T} \rightarrow \mathrm{A}$ polymorphisms of the paraoxonase 1 gene and the $959 \mathrm{G} \rightarrow \mathrm{C}$ polymorphism of the paraoxonase 2 gene were associated with BMD for the lumbar spine or femoral neck in postmenopausal women, with the $584 G G, 172 T T$, and $959 C C$ genotypes representing risk factors for reduced bone mass. None of these three polymorphisms was associated with BMD in
\end{abstract}

\footnotetext{
Y. Yamada $(\bowtie)$

Department of Gene Therapy,

Gifu International Institute of Biotechnology,

1-1 Naka-Fudogaoka, Kakamigahara,

Gifu 504-0838, Japan

E-mail: yoyamada@giib.or.jp

Tel.: + 81-583-714646

Fax: $+81-583-714412$

F. Ando $\cdot$ N. Niino $\cdot$ H. Shimokata

Department of Epidemiology,

National Institute for Longevity Sciences,

Obu, Aichi, Japan

T. Miki

Department of Geriatric Medicine,

Ehime University School of Medicine,

Shigenobu, Ehime, Japan
}

premenopausal women or in men. Our results suggest that the paraoxonase 1 and 2 genes are candidate loci for reduced bone mass in postmenopausal Japanese women.

Keywords Bone mineral density - Genetics ·

Osteoporosis $\cdot$ Paraoxonase $\cdot$ Polymorphism

\section{Introduction}

Osteoporosis is characterized by a reduction in bone mineral density (BMD) and a deterioration in the microarchitecture of bone, both of which result in an increased susceptibility to fractures (Kanis et al. 1994). Although several environmental factors, such as diet and physical exercise, influence BMD, a genetic contribution to the etiology of osteoporosis has been recognized (Pocock et al. 1987). Genetic linkage analyses (Devoto et al. 1998; Johnson et al. 1997; Morrison et al. 1994) and candidate gene association studies (Morrison et al. 1994; Uitterlinden et al. 1998; Yamada et al. 2001) have thus implicated several loci and candidate genes in the regulation of bone mass and the pathogenesis of osteoporotic fractures. The genes that contribute to genetic susceptibility to osteoporosis, however, remain to be identified definitively.

Oxidative stress may affect cellular functions in various pathological conditions, including osteoporosis (Basu et al. 2001; Garrett et al. 1990). Recent evidence has suggested that lipid oxidation contributes to the development of osteoporosis (Parhami et al. 2000). In vitro studies indicate that lipid oxidation products promote osteoblastic differentiation of vascular cells and inhibit such differentiation of bone cells (Parhami et al. 1997). Oxidation products of low-density lipoprotein (LDL) also promote osteoporotic loss of bone by inducing progenitor marrow stromal cells to undergo adipogenic rather than osteogenic differentiation (Parhami et al. 1999).

Paraoxonase 1 (PON1) is a calcium-dependent esterase that is closely associated with high-density 
lipoprotein (HDL)-containing apolipoprotein A-I and is thought to confer antioxidant properties on HDL by preventing the accumulation of lipid peroxidation products (Mackness et al. 1991). This property of PON1 accounts for its ability to protect against atherosclerosis. In addition to the PON1 gene $(P O N 1)$, related genes designated PON2 and PON3 have been identified in the human genome and are linked with $P O N 1$ on chromosome 7q21-q22 (Primo-Parmo et al. 1996). Two single nucleotide polymorphisms (SNPs), 584A $\rightarrow \mathrm{G}$ (Gln192 Arg; GenBank accession no. M63012) and 172T $\rightarrow$ A (Leu55Met; accession no. M63012), of PON1 and a 959G $\rightarrow$ C (Cys311Ser; accession no. L48513) SNP of $P O N 2$ have been associated with coronary artery disease (Ruiz et al. 1995; Serrato and Marian 1995; Garin et al. 1997; Sanghera et al. 1998). Although PON1 catalyzes the reduction of oxidized LDL and thereby may affect bone remodeling, the possible relations of these SNPs to BMD have not been determined.

We have now examined whether the $584 \mathrm{~A} \rightarrow \mathrm{G}$ (Gln192Arg) and $172 \mathrm{~T} \rightarrow \mathrm{A}$ (Leu55Met) SNPs of PON1 and the $959 \mathrm{G} \rightarrow \mathrm{C}$ (Cys311Ser) SNP of PON2 are associated with BMD in women or men in a largescale, population-based study.

\section{Subjects and methods}

Study population

The National Institute for Longevity Sciences-Longitudinal Study of Aging (NILS-LSA) is a population-based prospective cohort study of aging and age-related diseases (Shimokata et al. 2000). The subjects of the NILS-LSA are stratified by both age and gender and are randomly selected from resident registrations in the city of Obu and town of Higashiura in central Japan. The lifestyle of residents of this area is typical of that of individuals in most regions of Japan. The numbers of men and women recruited are similar, and the baseline age is $40-79$ years, with similar numbers of participants in each decade $(40 \mathrm{~s}, 50 \mathrm{~s}, 60 \mathrm{~s}, 70 \mathrm{~s})$. The subjects will be followed up every 2 years.

All participants are subjected at a special center to a detailed examination, which includes not only medical evaluation but also assessment of exercise physiology, body composition, nutrition, and psychology. Individuals with disorders known to cause abnormalities of bone metabolism, including diabetes mellitus, renal diseases, rheumatoid arthritis, as well as thyroid, parathyroid, and other endocrinologic diseases, were excluded from the study. Women who had taken drugs such as estrogen, progesterone, glucocorticoids, and bisphosphonates were also excluded.

We examined the possible association of BMD with the $584 \mathrm{~A} \rightarrow \mathrm{G}(\mathrm{G} \ln 192 \mathrm{Arg})$ SNP of PON1 in 2,199 participants (1,087 women, 1,112 men), with the 172T $\rightarrow$ A (Leu55Met) SNP of PON1 in 2,210 participants (1,092 women, 1,118 men), and with the 959G $\rightarrow$ C (Cys311Ser) SNP of PON2 in 2,219 participants (1,094 women, 1,125 men). The study protocol was approved by the Committee on Ethics of Human Research of National Chubu Hospital and the NILS, and written informed consent was obtained from each subject.

\section{Measurement of BMD}

BMD for the lumbar spine (L2-L4) and right femoral neck was measured by dual-energy X-ray absorptiometry (DEXA) (QDR 4500; Hologic, Bedford, MA, USA). The coefficients of variance of the DEXA instrument were $0.9 \%$ for $\mathrm{L} 2-\mathrm{L} 4$ and $1.3 \%$ for the femoral neck.

Determination of genotypes

Genotypes were determined with a fluorescence- or colorimetrybased allele-specific DNA primer-probe assay system (Toyobo Gene Analysis, Tsuruga, Japan).

For determination of genotype of the $584 \mathrm{~A} \rightarrow \mathrm{G}$ (Gln192Arg) SNP, the polymorphic region of PON1 was amplified by the polymerase chain reaction (PCR) with a sense primer labeled at the 5' end with biotin (5'-GAATGATATTGTTGCTGTGGGACC-3') and allele-specific antisense primers (5'-AACCCAAATACATCTCCCAGGAXTG-3' or 5'-ACCCAAATACATCTCCCAGGAXCG-3').

For determination of $172 \mathrm{~T} \rightarrow \mathrm{A}$ (Leu55Met) genotype, the polymorphic region of PON1 was similarly amplified with a sense primer (5'-TCTGGCAGAAACTGGCTCTGAA-3') and an antisense primer labeled at the 5' end with biotin (5'-GCTAATGAAAGCCAGTCCATTA-3').

For determination of $959 \mathrm{G} \rightarrow \mathrm{C}$ (Cys311Ser) genotype, the polymorphic region of PON2 was amplified by PCR with allelespecific sense primers labeled at the 5' end with either fluorescein isothiocyanate (5'- CGCATCCAGAACATTCTAXGT-3') or Texas red (5'- CCGCATCCAGAACATTCTAXCT-3') and with an antisense primer labeled at the 5' end with biotin (5'-GGCATAAACTGTAGTCACTGTAGGC-3').

The reaction mixtures $(25 \mu \mathrm{l})$ contained $20 \mathrm{ng}$ of DNA, $5 \mathrm{pmol}$ of each primer, $0.2 \mathrm{mmol} / 1$ of each deoxynucleoside triphosphate, $1.4 \mathrm{mmol} / 1 \mathrm{MgSO}_{4}(584 \mathrm{~A} \rightarrow \mathrm{G}$ and $172 \mathrm{~T} \rightarrow \mathrm{A}$ genotypes) or $1.8 \mathrm{mmol} / 1 \mathrm{MgCl}_{2}(959 \mathrm{G} \rightarrow \mathrm{C}$ genotype), and $1 \mathrm{U}$ of DNA polymerase (rTaq or KODplus; Toyobo, Osaka, Japan) in the respective DNA polymerase buffer. The amplification protocol comprised initial denaturation at $95^{\circ} \mathrm{C}$ for 5 min; 35 cycles $(584 \mathrm{~A} \rightarrow \mathrm{G}$ and 959G $\rightarrow \mathrm{C}$ genotypes) or 40 cycles (172T $\rightarrow \mathrm{A}$ genotype) of denaturation at $95^{\circ} \mathrm{C}$ for $30 \mathrm{~s}$, annealing at $63^{\circ} \mathrm{C}(584 \mathrm{~A} \rightarrow \mathrm{G}$ genotype), $55^{\circ} \mathrm{C}\left(172 \mathrm{~T} \rightarrow \mathrm{A}\right.$ genotype), or $60^{\circ} \mathrm{C}(959 \mathrm{G} \rightarrow \mathrm{C}$ genotype) for $30 \mathrm{~s}$, and extension at $68^{\circ} \mathrm{C}$ for $30 \mathrm{~s}$; and a final extension at $68^{\circ} \mathrm{C}$ for $2 \mathrm{~min}$.

For determination of $584 \mathrm{~A} \rightarrow \mathrm{G}$ and $172 \mathrm{~T} \rightarrow \mathrm{A}$ genotypes, amplified DNA was denatured with $0.3 \mathrm{~mol} / 1 \mathrm{NaOH}$ and then subjected to hybridization at $37^{\circ} \mathrm{C}$ for $30 \mathrm{~min}$ in hybridization buffer containing $35 \% \quad(584 \mathrm{~A} \rightarrow \mathrm{G}$ genotype $)$ or $32.5 \%$ (172T $\rightarrow$ A genotype) formamide with allele-specific capture probes (5'-ACATCTCCCAGGAXTGTAAGTAG-3' or 5'-ACATCTCCCAGGAXCGTAAGTAG-3' for 584A $\rightarrow$ G genotype, and 5'-GAAGACTTGGAGATACTGCC-3' or 5'-GAAGACATGGAGATACTGCC-3' for 172T $\rightarrow$ A genotype) fixed to the bottom of the wells of a 96-well plate. After thorough washing of the wells, alkaline phosphatase-conjugated streptavidin was added to each, and the plate was incubated at $37^{\circ} \mathrm{C}$ for $15 \mathrm{~min}$ with agitation. The wells were again washed, and after the addition of a solution containing $0.8 \mathrm{mmol} / 1 \quad 2$-(4-iodophenyl)-3-(4-nitrophenyl)-5-(2,4-disulfophenyl)$2 \mathrm{H}$-tetrazolium (monosodium salt) and $0.4 \mathrm{mmol} / 1$ 5-bromo-4-chloro3-indolyl phosphate $p$-toluidine salt, absorbance at $450 \mathrm{~nm}$ was measured.

For determination of $959 \mathrm{G} \rightarrow \mathrm{C}$ genotype, amplified DNA was incubated in a solution containing streptavidin-conjugated magnetic beads in the wells of a 96-well plate at room temperature. The plate was placed on a magnetic stand, and the supernatants were then collected from each well, transferred to the wells of a 96-well plate containing $0.01 \mathrm{~mol} / 1 \mathrm{NaOH}$, and measured for fluorescence with a microplate reader (Fluoroscan Ascent; Dainippon Pharmaceutical, Osaka, Japan) at excitation and emission wavelengths of 485 and $538 \mathrm{~nm}$, respectively, for fluorescein isothiocyanate and of 584 and $612 \mathrm{~nm}$, respectively, for Texas red.

To confirm the accuracy of genotyping by this method, we selected 50 DNA samples at random and subjected them to PCR and restriction fragment-length polymorphism analysis or to direct DNA sequencing of PCR products. In each instance, the genotype determined by the allele-specific DNA primer-probe assay system was identical to that determined by the confirmatory methods. 
Assay for serum activity of PON1

Venous blood was collected from subjects after an overnight fast. Blood samples were centrifuged at $1600 \times g$ for $15 \mathrm{~min}$ at $4^{\circ} \mathrm{C}$, and serum was separated and stored at $-80^{\circ} \mathrm{C}$ until assayed. The serum activity of PON1 was measured as previously described (Mackness et al. 1997). The intra- and interassay coefficients of variance were $<2.6$ and $<2.3 \%$, respectively.

Statistical analysis

Quantitative data were compared among three groups by one-way analysis of variance and the Tukey-Kramer post hoc test, and between two groups by the unpaired Student's $t$ test. BMD values were analyzed with or without adjustment for age by the least squares method in a general linear model (SAS, SAS Institute, Cary, NC, USA). Allele frequencies were estimated by the genecounting method, and the chi-square test was used to identify significant departure from Hardy-Weinberg equilibrium. Haplotype analysis was performed with SAS/Genetics (SAS Institute). Correlation between the serum activity of PON1 and BMD was determined by simple regression analysis. Unless indicated otherwise, a $P$ value of $<0.05$ was considered statistically significant.

\section{Results}

The distribution of combined genotypes of three SNPs is shown in Table 1. Linkage disequilibrium was apparent between the 584A $\rightarrow \mathrm{G}(\mathrm{Gln} 192 \mathrm{Arg})$ and $172 \mathrm{~T} \rightarrow \mathrm{A}$ (Leu55Met) SNPs of PON1 [D', pairwise linkage disequilibrium coefficient $(D / D$ max $), 0.4254 ; r$, standardized linkage disequilibrium coefficient, $0.1673 ; P$ $<0.0001$ ], between the PON1 584A $\rightarrow \mathrm{G}$ and PON2 959G $\rightarrow$ C (Cys311Ser) SNPs $\left(D^{\prime}, 0.2112 ; r, 0.1470 ; P\right.$ $<0.0001$ ), and between the PON1 172A $\rightarrow \mathrm{T}$ and PON2 $959 \mathrm{G} \rightarrow$ C SNPs $\left(D^{\prime}, 0.2491 ; r, 0.1421 ; P<0.0001\right)$.

Characteristics of study subjects according to genotypes for the $584 \mathrm{~A} \rightarrow \mathrm{G}$ SNP or $172 \mathrm{~T} \rightarrow \mathrm{A}$ SNP of PON1 or for the $959 \mathrm{G} \rightarrow \mathrm{C} \mathrm{SNP}$ of PON2 are shown in Table 2. The distributions of genotypes were in HardyWeinberg equilibrium for premenopausal or postmenopausal women or for men in three SNPs. There was no difference in age or body mass index for premenopausal or postmenopausal women or for men among genotypes of each SNP.

The relation of the $584 \mathrm{~A} \rightarrow \mathrm{G}$ SNP of PON1 to BMD was examined (Table 3). To examine the possible influence of menopause on the relation between genotype and BMD, we analyzed BMD and other characteristics for premenopausal and postmenopausal women independently. Given the multiple comparisons of genotypes with BMD, we considered a $P$ value of $<0.01$ to be significant for such associations. For premenopausal women, BMD was not associated with 584A $\rightarrow \mathrm{G}$ genotype with or without adjustment for age. In contrast, for postmenopausal women, BMD for the femoral neck was significantly lower in those with the $G G$ genotype than in those with the $G A$ or $A A$ genotype. After adjustment for age, BMD for the femoral neck was also significantly lower in postmenopausal women with the $G G$ genotype than in those with the $G A$ or $A A$ genotype or the $G A$ genotype. The difference in adjusted BMD between the $G G$ genotype and the $G A$ or $A A$ genotype (expressed as a percentage of the corresponding larger value) in postmenopausal women was

Table 1 Distribution of combined genotypes of polymorphisms of PON1 and PON2 among study subjects $(n=2,196)$. Data are numbers of subjects $(\%)$

\begin{tabular}{llcll}
\hline $\begin{array}{l}\text { PON1 } \\
\text { 584A } \rightarrow \mathrm{G}\end{array}$ & \multicolumn{2}{l}{$P O N 1$ 172T $\rightarrow \mathrm{A}$} & \multirow{2}{*}{$\begin{array}{l}\text { PON2 } \\
\text { 959G } \rightarrow \mathrm{C}\end{array}$} \\
\cline { 2 - 4 } & $T T$ & $T A$ & $A A$ & \\
\hline$G G$ & $811(36.93)$ & $0(0)$ & $0(0)$ & $C C$ \\
& $141(6.42)$ & $0(0)$ & $0(0)$ & $C G$ \\
$G A$ & $13(0.59)$ & $0(0)$ & $0(0)$ & $G G$ \\
& $470(21.40)$ & $59(2.69)$ & $0(0)$ & $C C$ \\
$A A$ & $292(13.30)$ & $133(6.06)$ & $1(0.05)$ & $C G$ \\
& $26(1.18)$ & $15(0.68)$ & $1(0.05)$ & $G G$ \\
& $64(2.91)$ & $18(0.82)$ & $2(0.09)$ & $C C$ \\
& $57(2.60)$ & $36(1.64)$ & $8(0.36)$ & $C G$ \\
& $19(0.87)$ & $24(1.09)$ & $6(0.27)$ & $G G$ \\
\hline
\end{tabular}

Table 2 Characteristics of study subjects according to the 584A $\rightarrow \mathrm{G}$ (Gln192Arg) or 172T $\rightarrow$ A (Leu55Met) genotype of PON1 or the $959 \mathrm{G} \rightarrow \mathrm{C}(\mathrm{Cys} 311 \mathrm{Ser})$ genotype of PON2. Data are means \pm SE. BMI body mass index

\begin{tabular}{|c|c|c|c|c|c|c|c|c|c|}
\hline Characteristic & \multicolumn{3}{|c|}{$584 \mathrm{~A} \rightarrow \mathrm{G}(\mathrm{Gln} 192 \mathrm{Arg})$} & \multicolumn{3}{|c|}{$172 \mathrm{~T} \rightarrow \mathrm{A}($ Leu55Met $)$} & \multicolumn{3}{|c|}{ 959G $\rightarrow$ C (Cys311Ser) } \\
\hline Number $(\%)$ & 107 (38.6) & $136(49.1)$ & $34(12.3)$ & $239(86.0)$ & 35 (12.6) & $4(1.4)$ & $173(62.2)$ & $92(33.1)$ & $13(4.7)$ \\
\hline Age (years) & $46.1 \pm 0.4$ & $46.2 \pm 0.4$ & $46.6 \pm 0.8$ & $46.0 \pm 0.3$ & $47.1 \pm 0.8$ & $48.3 \pm 2.3$ & $46.2 \pm 0.4$ & $46.2 \pm 0.5$ & $45.7 \pm 1.3$ \\
\hline $\mathrm{BMI}\left(\mathrm{kg} / \mathrm{m}^{2}\right)$ & $22.9 \pm 0.3$ & $22.7 \pm 0.3$ & $22.7 \pm 0.6$ & $22.8 \pm 0.2$ & $22.5 \pm 0.5$ & $22.2 \pm 1.6$ & $22.9 \pm 0.2$ & $22.6 \pm 0.3$ & $22.8 \pm 0.9$ \\
\hline Age (years) & $64.1 \pm 0.4$ & $63.8 \pm 0.5$ & $64.1 \pm 0.9$ & $64.1 \pm 0.3$ & $63.4 \pm 0.8$ & $63.4 \pm 3.8$ & $64.1 \pm 0.4$ & $63.5 \pm 0.6$ & $63.9 \pm 1.4$ \\
\hline BMI $\left(\mathrm{kg} / \mathrm{m}^{2}\right)$ & $22.8 \pm 0.2$ & $23.0 \pm 0.2$ & $23.5 \pm 0.4$ & $23.0 \pm 0.1$ & $22.7 \pm 0.3$ & $23.9 \pm 1.5$ & $22.9 \pm 0.1$ & $23.2 \pm 0.2$ & $23.3 \pm 0.5$ \\
\hline \multicolumn{10}{|l|}{ Men } \\
\hline Number (\%) & $493(44.3)$ & $504(45.3)$ & 115 & $965(86.3)$ & 144 (12.9) & $9(0.8)$ & $720(64.0)$ & $351(31.2)$ & $54(4.8)$ \\
\hline Age (years) & $59.2 \pm 0.5$ & $59.2 \pm 0.5$ & $58.7 \pm 1.0$ & $59.0 \pm 0.4$ & $60.0 \pm 0.9$ & $59.4 \pm 3.6$ & $59.1 \pm 0.4$ & $59.2 \pm 0.6$ & $59.2 \pm 1.5$ \\
\hline BMI $\left(\mathrm{kg} / \mathrm{m}^{2}\right)$ & $22.9 \pm 0.2$ & $23.1 \pm 0.2$ & $22.6 \pm 0.3$ & $23.0 \pm 0.1$ & $22.8 \pm 0.2$ & $24.0 \pm 1.2$ & $23.1 \pm 0.1$ & $22.7 \pm 0.2$ & $23.0 \pm 0.4$ \\
\hline
\end{tabular}


Table 6 Bone mineral density (BMD) of premenopausal or postmenopausal women or of men according to haplotypes of three polymorphisms. Data are means $\pm \mathrm{SE}$

\begin{tabular}{|c|c|c|c|c|c|c|}
\hline \multirow[t]{2}{*}{ BMD } & \multicolumn{6}{|c|}{ Haplotype $[584 \mathrm{~A} \rightarrow \mathrm{G}(P O N 1), 172 \mathrm{~T} \rightarrow \mathrm{A}(P O N 1), 959 \mathrm{G} \rightarrow \mathrm{C}(P O N 2)]$} \\
\hline & $G T C$ & $G T G$ & $A T C$ & $A T G$ & $A A C$ & $A A G$ \\
\hline \multicolumn{7}{|l|}{ Premenopausal women } \\
\hline No. of chromosomes $(\%)$ & $314(57.40)$ & $31(5.67)$ & $106(19.38)$ & $55(10.05)$ & $9(1.65)$ & $32(5.85)$ \\
\hline L2-L4 & $1.034 \pm 0.007$ & $1.012 \pm 0.022$ & $1.014 \pm 0.012$ & $1.033 \pm 0.017$ & $0.999 \pm 0.041$ & $0.986 \pm 0.022$ \\
\hline Femoral neck & $0.776 \pm 0.006$ & $0.783 \pm 0.018$ & $0.766 \pm 0.010$ & $0.781 \pm 0.013$ & $0.734 \pm 0.033$ & $0.751 \pm 0.018$ \\
\hline \multicolumn{7}{|l|}{ Postmenopausal women } \\
\hline No. of chromosomes $(\%)$ & $1016(63.18)$ & $66(4.10)$ & $259(16.11)$ & $150(9.33)$ & $33(2.05)$ & $84(5.22)$ \\
\hline L2-L4 & $0.802 \pm 0.005$ & $0.832 \pm 0.019$ & $0.817 \pm 0.009$ & $0.802 \pm 0.012$ & $0.869 \pm 0.026$ & $0.845 \pm 0.017$ \\
\hline Femoral neck & $0.638 \pm 0.003 *$ & $0.662 \pm 0.013$ & $0.644 \pm 0.007$ & $0.658 \pm 0.009$ & $0.700 \pm 0.018$ & $0.656 \pm 0.011$ \\
\hline \multicolumn{7}{|l|}{ Men } \\
\hline No. of chromosomes $(\%)$ & $1366(62.03)$ & $110(5.00)$ & $339(15.40)$ & $227(10.31)$ & $46(2.09)$ & $113(5.13)$ \\
\hline $\mathrm{L} 2-\mathrm{L} 4$ & $0.979 \pm 0.004$ & $0.970 \pm 0.015$ & $0.989 \pm 0.009$ & $0.988 \pm 0.011$ & $0.993 \pm 0.024$ & $0.984 \pm 0.015$ \\
\hline Femoral neck & $0.750 \pm 0.003$ & $0.747 \pm 0.011$ & $0.757 \pm 0.006$ & $0.756 \pm 0.008$ & $0.765 \pm 0.017$ & $0.751 \pm 0.011$ \\
\hline
\end{tabular}

$* P<0.01$ versus $A A C$

Table 7 Serum activity (nmol min $\mathrm{ml}^{-1}$ ) of PON1 in study subjects according to the $584 \mathrm{~A} \rightarrow \mathrm{G}(\mathrm{Gln} 192 \mathrm{Arg})$ and $172 \mathrm{~T} \rightarrow \mathrm{A}(\mathrm{Leu} 55 \mathrm{Met})$ genotypes of PON1 and the $959 \mathrm{G} \rightarrow \mathrm{C}$ (Cys311Ser) genotype of PON2. Data are means $\pm \mathrm{SE}$

\begin{tabular}{|c|c|c|c|}
\hline & Total subjects & Women & Men \\
\hline \multicolumn{4}{|c|}{ 584A $\rightarrow \mathrm{G}(\mathrm{Gln} 192 \mathrm{Arg})$ genotype } \\
\hline$G G$ & $503.7 \pm 3.0(n=969)$ & $516.5 \pm 4.1(n=476)$ & $491.2 \pm 4.2(n=493)$ \\
\hline$G A$ & $325.6 \pm 2.9(n=993)^{*}$ & $333.5 \pm 4.0(n=489)^{*}$ & $317.9 \pm 4.1(n=504)^{*}$ \\
\hline$A A$ & $139.3 \pm 6.1(n=237)^{* \dagger}$ & $145.7 \pm 8.3(n=122)^{*} \dagger$ & $132.2 \pm 8.9(n=115)^{* \dagger}$ \\
\hline \multicolumn{4}{|c|}{$172 \mathrm{~T} \rightarrow \mathrm{A}($ Leu55Met) genotype } \\
\hline$T T$ & $407.2 \pm 3.3(n=1906)$ & $413.9 \pm 4.7(n=941)$ & $400.5 \pm 4.5(n=965)$ \\
\hline$T A$ & $256.5 \pm 8.4(n=286) \ddagger$ & $268.7 \pm 12.2(n=142) \ddagger$ & $244.5 \pm 11.5(n=144) \ddagger$ \\
\hline$A A$ & $101.9 \pm 32.9(n=18) \pm \S$ & $111.5 \pm 49.1(n=9) \ddagger$ & $93.3 \pm 43.9(n=9) \pm$ \\
\hline \multicolumn{4}{|c|}{ 959G $\rightarrow$ C (Cys311Ser) genotype } \\
\hline$C C$ & $408.9 \pm 3.9(n=1444)$ & $415.6 \pm 5.6(n=724)$ & $402.0 \pm 5.5(n=720)$ \\
\hline$C G$ & $349.1 \pm 5.8(n=670) \dagger \uparrow$ & $361.7 \pm 8.4(n=319) \dagger \dagger$ & $337.4 \pm 7.9(n=351) \dagger \dagger$ \\
\hline$G G$ & $285.2 \pm 15.1(n=105) \dagger \dagger \#$ & $267.3 \pm 21.9(n=51) \dagger \dagger \#$ & $302.4 \pm 20.7(n=54) \dagger \dagger$ \\
\hline \multirow{4}{*}{\multicolumn{2}{|c|}{$\begin{array}{l}* P=0.0001 \text { versus } G G \\
\dagger P=0.0001 \text { versus } G A \\
\ddagger P=0.0001 \text { versus } T T \\
\S P=0.0001 \text { versus } T A\end{array}$}} & $\| P<0.005$ versus $T A$ & \\
\hline & & $\dagger \dagger P=0.0001$ versus $C C$ & \\
\hline & & $\# P<0.0005$ versus $C G$ & \\
\hline & & & \\
\hline
\end{tabular}

for the femoral neck was significantly lower in those with the GTC haplotype than in those with the $A A C$ haplotype. For premenopausal women or for men, BMD did not differ among haplotypes.

We examined the relation of three SNPs with the serum activity of PON1 (Table 7). There was a significant association between the serum activity of PON1 and $584 \mathrm{~A} \rightarrow \mathrm{G}, 172 \mathrm{~T} \rightarrow \mathrm{A}$, and $959 \mathrm{G} \rightarrow \mathrm{C}$ genotypes both for women and for men. With regard to the $584 \mathrm{~A} \rightarrow \mathrm{G}$ genotype, the activity of PON1 was higher in individuals with the $G G$ genotype than in those with the $G A$ genotype or those with the $A A$ genotype; the activity was also higher in those with the $G A$ genotype than in those with the $A A$ genotype. For the $172 \mathrm{~T} \rightarrow \mathrm{A}$ genotype, the activity of PON1 was higher in individuals with the $T T$ genotype than in those with the $T A$ or those with the $A A$ genotypes; the activity was also higher in those with the $T A$ genotype than in those with the $A A$ genotype. With respect to the $959 \mathrm{G} \rightarrow \mathrm{C}$ genotype, the serum activity of PON1 was higher in individuals with the $C C$ genotype than in those with the $C G$ or those with the $G G$ genotypes; for total subjects and for women, the activity was also higher in those with the $C G$ genotype than in those with the $G G$ genotype.

Finally, we examined the correlation between the serum activity of PON1 and BMD (Fig. 1). There was no significant relation of the serum activity of PON1 with BMD for the lumbar spine $(r=0.010, P=0.844)$ or for the femoral neck $(r=0.014, P=0.683)$ in postmenopausal women.

\section{Discussion}

We have shown that the $584 \mathrm{~A} \rightarrow \mathrm{G}(\mathrm{G} \ln 192 \mathrm{Arg})$ and $172 \mathrm{~T} \rightarrow \mathrm{A}$ (Leu55Met) SNPs of PON1 and the 959G $\rightarrow$ C (Cys311Ser) SNP of PON2 are associated with BMD for the lumbar spine or femoral neck in postmenopausal Japanese women, and that the $584 G G$, $172 T T$, and $959 C C$ genotypes represent risk factors for 
Fig. 1 Correlation of serum activity of PON1 with bone mineral density (BMD) for the lumbar spine (L2-L4) (left panel) or femoral neck (right panel) in postmenopausal women $(n=816)$
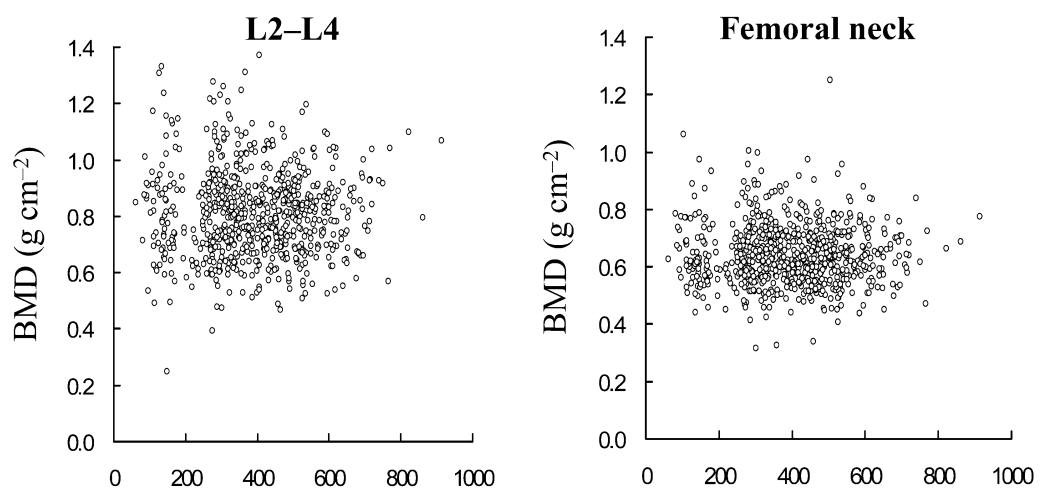

Serum activity of PON1 $\left(\mathrm{nmol} \mathrm{min}-1 \mathrm{~mL}^{-1}\right)$ reduced bone mass. Haplotype analysis revealed that the $G T C$ haplotype exhibited the lowest BMD and the $A A C$ haplotype the highest BMD in postmenopausal women. There was no significant association of polymorphisms of $P O N 1$ or $P O N 2$ with BMD in premenopausal women or in men.

The three SNPs examined in the present study have been previously associated with the activity of PON1 in serum or plasma. We measured the serum activity of PON1 in the present study population to confirm the effects of three SNPs on the activity. Humbert et al. (1993) determined that the $584 G$ (192Arg) allele is associated with a higher activity of PON1 in plasma than is the 584A (192Gln) allele. Garin et al. (1997) showed that the plasma concentrations and activities of PON1 decreased according to the rank order of $172 \mathrm{~T} \rightarrow \mathrm{A}$ (Leu55Met) genotypes $T T>T A>A A$. Our present results are consistent with these previous observations (Garin et al. 1997; Humbert et al. 1993).

Mackness et al. (2000) showed that the $959 \mathrm{G} \rightarrow \mathrm{C}$ (Cys311Ser) SNP of PON2 also affects the serum activity of PON1; among individuals with type 2 diabetes, PON1 activity was highest in those with the $959 G G$ genotype. In contrast, our results demonstrate that the $G G$ genotype is associated with the lowest PON1 activity and that the $C C$ genotype exhibits the highest activity for both women and men.

In the present study, the $584 G G, 172 T T$, and $959 C C$ genotypes, which exhibited the highest serum activity of PON1, were associated with reduced BMD in postmenopausal women. A high serum activity of PON1 may result in a reduced concentration of lipid peroxidation products and might therefore be expected to prevent bone loss (Basu et al. 2001; Garrett et al. 1990; Parhami et al. 1997; Parhami et al. 1999; Parhami et al. 2000). The association between genotypes and BMD in our study is thus opposite to that anticipated from such a mechanism. The molecular mechanisms that underlie the association of SNPs of PON1 and PON2 with BMD thus remain unclear. It is possible that the SNPs examined in our study are in linkage disequilibrium with polymorphisms of other nearby genes that are determinants of BMD. Indeed, the interleukin- 6 gene $(7 \mathrm{q} 21)$ and calcitonin receptor gene (7q21.3), both of which have been associated with BMD (Ota et al. 1999; Ota et al. 2001; Taboulet et al. 1998), are located close to PON1 and PON2 (7q21q22). However, our present results suggest that $P O N 1$ and $P O N 2$ are candidate loci for reduced bone mass in postmenopausal Japanese women.

Acknowledgements We thank T. Kosaka (Azwell, Osaka, Japan) for measurement of serum PON1 activity. This work was supported in part by Research Grants for Longevity Sciences (12C-01) from the Ministry of Health, Labor, and Welfare of Japan (to Y.Y. and H.S.), and Health and Labor Sciences Research Grants for Comprehensive Research on Aging and Health (H15-Chojyu-014) from the Ministry of Health, Labor, and Welfare of Japan (to Y.Y., F.A., N.N., and H.S.).

\section{References}

Basu S, Michaelsson K, Olofsson H, Johansson S, Melhus H (2001) Association between oxidative stress and bone mineral density. Biochem Biophys Res Commun 288:275-279

Devoto M, Shimoya K, Caminis J, Ott J, Tenenhouse A, Whyte MP, Sereda L, Hall S, Considine E, Williams CJ, Tromp G, Kuivaniemi H, Ala-Kokko L, Prockop DJ, Spotila LD (1998) First-stage autosomal genome screen in extended pedigrees suggests genes predisposing to low bone mineral density on chromosomes $1 \mathrm{p}, 2 \mathrm{p}$ and $4 \mathrm{p}$. Eur J Hum Genet 6:151-157

Garin M-CB, James RW, Dussoix P, Blanché H, Passa P, Froguel P, Ruiz J (1997) Paraoxonase polymorphism Met-Leu54 is associated with modified serum concentrations of the enzyme. A possible link between the paraoxonase gene and increased risk of cardiovascular disease in diabetes. J Clin Invest 99:62-66

Garrett IR, Boyce BF, Oreffo RO, Bonewald L, Poser J, Mundy GR (1990) Oxygen-derived free radicals stimulate osteoclastic bone resorption in rodent bone in vitro and in vivo. $\mathrm{J}$ Clin Invest 85:632-639

Humbert R, Adler DA, Disteche CM, Hassett C, Omiecinski CJ, Furlong CE (1993) The molecular basis of the human serum paraoxonase activity polymorphism. Nature Genet 3:73-76

Johnson ML, Gong G, Kimberling W, Recker SM, Kimmel DB, Recker RB (1997) Linkage of a gene causing high bone mass to human chromosome 11 (11q12-13). Am J Hum Genet 60:13261332

Kanis JA, Melton LJ III, Christiansen C, Johnston CC, Khaltaev N (1994) The diagnosis of osteoporosis. J Bone Miner Res 9:1137-1141

Mackness MI, Arrol S, Durrington PN (1991) Paraoxonase prevents accumulation of lipoperoxides in low-density lipoprotein. FEBS Lett 286:152-154 
Mackness B, Mackness MI, Arrol S, Turkie W, Durrington PN (1997) Effect of the molecular polymorphisms of human paraoxonase (PON1) on the rate of hydrolysis of paraoxon. $\mathrm{Br}$ J Pharmacol 122:265-268

Mackness B, Durrington PN, Abuashia B, Boulton AJ, Mackness MI (2000) Low paraoxonase activity in type II diabetes mellitus complicated by retinopathy. Clin Sci 98:355-363

Morrison NA, Qi JC, Tokita A, Kelly PJ, Crofts L, Nguyen TV, Sambrook PN, Eisman JA (1994) Prediction of bone density from vitamin D receptor alleles. Nature 367:284-287

Ota N, Hunt SC, Nakajima T, Suzuki T, Hosoi T, Orimo H, Shirai Y, Emi M (1999) Linkage of interleukin 6 locus to human osteopenia by sibling pair analysis. Hum Genet 105:253-257

Ota N, Nakajima T, Nakazawa I, Suzuki T, Hosoi T, Orimo H, Inoue S, Shirai Y, Emi M (2001) A nucleotide variant in the promoter region of the interleukin-6 gene associated with decreased bone mineral density. J Hum Genet 46:267-272

Parhami F, Morrow AD, Balucan J, Leitinger N, Watson AD, Tintut Y, Berliner JA, Demer LL (1997) Lipid oxidation products have opposite effects on calcifying vascular cell and bone cell differentiation. A possible explanation for the paradox of arterial calcification in osteoporotic patients. Arterioscler Thromb Vasc Biol 17:680-687

Parhami F, Jackson SM, Tintut Y, Le V, Balucan JP, Territo M, demer LL (1999) Atherogenic diet and minimally oxidized low density lipoprotein inhibit osteogenic and promote adipogenic differentiation of marrow stromal cells. J Bone Miner Res 14:2067-2078

Parhami F, Garfinkel A, Demer LL (2000) Role of lipids in osteoporosis. Arterioscler Thromb Vasc Biol 20:2346-2348

Pocock NA, Eisman JA, Hopper JL, Yeates MG, Sambrook PN, Eberl S (1987) Genetic determinations of bone mass in adults: a twin study. J Clin Invest 80:706-710
Primo-Parmo SL, Sorenson RC, Teiber J, La Du BN (1996) The human serum paraoxonase/arylesterase gene (PON1) is one member of a multigene family. Genomics 33:498-507

Ruiz J, Blanché H, James RW, Garin M-CB, Vaisse C, Charpentier G, Cohen N, Morabia A, Passa P, Froguel P (1995) GlnArg192 polymorphism of paraoxonase and coronary artery disease in type 2 diabetes. Lancet 346:869-872

Sanghera DK, Aston CE, Sara N, Kamboh MI (1998) DNA polymorphisms in two paraoxonase genes (PON1 and PON2) are associated with the risk of coronary heart disease. Am J Hum Genet 62:36-44

Serrato M, Marian AJ (1995) A variant of human paraoxonase/ arylesterase (HUMPONA) gene is a risk factor for coronary artery disease. J Clin Invest 96:3005-3008

Shimokata H, Ando F, Niino N (2000) A new comprehensive study on aging - the National Institute for Longevity Sciences, Longitudinal Study of Aging (NILS-LSA). J Epidemiol 10: S1-S9

Taboulet J, Frenkian M, Frendo JL, Feingold N, Jullienne A, de Vernejoul MC (1998) Calcitonin receptor polymorphism is associated with a decreased fracture risk in post-menopausal women. Hum Mol Genet 7:2129-2133

Uitterlinden AG, Burger H, Huang Q, Yue F, McGuigan FEA, Grant SFA, Hofman A, van Leeuwen JPTM, Pols HAP, Ralston SH (1998) Relation of alleles of the collagen type $\mathrm{I} \alpha 1$ gene to bone density and the risk of osteoporotic fractures in postmenopausal women. N Engl J Med 338:1016-1021

Yamada Y, Ando F, Niino N, Shimokata H (2001) Transforming growth factor- $\beta 1$ gene polymorphism and bone mineral density. JAMA 285:167-168 